\title{
LINGUISTIC THEORY, UNIVERSALS, AND SLAVIC ACCENTUATION
}

\section{FREDERIK KORTIANDT}

[In theil review of Garde's monograph on the history of Slavic accentuation, Halle and Kiparsky havo sketched an alternative framework. The author compares the two theories and evaluates the differences against the background of previous work in the field.]

0. Paul Garde's monograph on the history of Slavic accentuation (1976) has been reviewed by Morris Halle and Paul Kiparsky (1981). The major part of thoir review article is a sketch of an alternative framework which, according to the authors, "makes it possible to gain a deeper understanding of the accontual phenomena of Baltic and Slavic" (161). They conclude their article as follows (180):

Tho outlook reflected in G's analysis is that of structuralism at its best: and it shares with empiricist varieties of structuralism an agnostic attitude toward linguistic theory and universals. This attitude appears in G's reluctance to assign phonological features to such prosodic catogories as STRONG and CIRCUMFLEX, and in his skepticism toward the typological considerations that have traditionally played an important role in the field. Wo have tried to demonstrate, in the second half of this review, that such skepticism is unjustified, and that an approach through a richer theorctical framework is rewarded by new insights that elude even Garde's careful investigations.

As Garde points out himself $(x)$, his book is based ontirely on second-hand materials, in particular on the work by Dybo and Illič-Svityč. Elsewhere I have argued that Garde's original contributions to the history of Slavic accentuation cannot be maintained $(1978 \mathrm{a})^{1}$. In this article I intend to show that the "new insights"

1 This is not to deny the usefulness of Garde's book, which is the first major handbook in the field since Stang's (1957), as an introduction to the new insights which the work by Dybo and Illič-Svityč has yielded. It is regrettable that an important part of the relevant literature had escaped Garde's attention when he wrote the book and that he has not been able to 
which Halle and Kiparsky derive from their "richer theoretical framework" are partly not new and partly incorrect. I shall refrain from discussing here the numerous results of recent research which have not found their way into either Garde's or Halle and Kiparsky's account.

1. Halle and Kiparsky regard as an essential difference between their framework and Garde's that "instead of G's abstract rule feature strong/weak, we make use of the phonetic feature [accented] which we identify with the feature [upper register]" (161). The binary feature [accented] cross-classifies with the binary featuro [high tone] to yield four relative pitch levels. This is quite unlike anything attested in the Balto-Slavic linguistic area.

Both the Basic Accentuation Principle, according to which the accent is placed on the leftmost prominence peak in the word, and the hypothesis that it reflects an earlier pitch level system were first forward by Dybo (1973: 10, ef. also Dybo et al. 1978). Typological parallels can be found not only in Caucasian languages, from which Dybo drew his examples, but also on the Canadian Pacific coast (Kortlandt 1975b: 32, ef. now Rath 1981). It appears that an increase of reliable descriptive work on the relevant languages is a prerequisite for any significant progress in this fiold of study.

2. Gardo is reluctant to assign phonetic features to his Balto-Slavic prosodic categories (5): "We employ thus the terms 'acute' and 'circumflex', which conventionally designate features whose exact phonetic nature escapes us. We know only that we are dealing with a tonal opposition, in the sense that it affects neither the quality of the vowels, nor their quantity, and that it is independent of the accent" 2 . Halle and Kiparsky are less reluctant (164): "We shall assume that in Balto-Slavic, as in modern Lithuanian, the so-called acute intonation was originally a $\mathrm{H}$ (igh) tone, whereas the so-called circumflex intonation was a rising melody: $\mathbf{L}(\mathrm{ow}) \mathrm{H}$ (igh). Accent and tone are independent phonological features, governed by separate rules". This difference

avoid the large number of inaccuracies and misprints in his account of the facts, ef. Kortlandt 1978a: 80ff.

2 This is Halle and Kiparsky's translation (161). 
in reluctance betrays a profound methodological difference. What was the reason for Garde's reluctance? It is stated in the lines which immediately precede the quotation just given: "The Lithuanian and the Latvian evidence are divergent on this point: in Lithuanian the acute is falling and the circumflex rising, but in Latvian the opposite holds. The Slavic evidence cannot be used because all Slavic languages have passed through a stage when the conal opposition had become a quantitative opposition" (5). Unlike the earlier quotation, these lines have not been reproduced by Halle and Kiparsky. They reveal a motivation which is quite different from the "agnostic attitude toward linguistic, theory and universals" which Halle and Kiparsky attribute to Garde. It is obvious that any statement which goes beyond the immediately observable facts is to a certain extent based on typological considerations. The root of the disagreement is the role of the facts in the evaluation of the evidence. Garde does not specify the phonetic character of 'acute' and 'circumflex' because the evidence is ambiguous. He thereby indicates a topic for further research. Halle and Kiparsky's appeal to the facts is limited to the data which can be used as an illustration of their theoretical reflections. In this way they block the road toward a better understanding of the integral body of facts.

The loose attitude toward the facts is evident from the way Halle and Kiparsky treat the Baltic data. They devote no more than a footnote to the Latvian and Prussian counter-evidence, from which they conclude (164): "These facts raise a number of questions about any account which assumes that the Lith. development was also common Balto-Slavic". The caution which one would expect on the basis of this remark is not reflected in any reluctance to specify the phonetic character of the Balto-Slavic prosodic categories in the main text. Moreover, the interpretation of the Lithuanian evidence is not so straightforward as Halle and Kiparsky suggest. As a general rule, the acute is realized as a glottal stop in Žemaitian and as a falling tone in the archaic dialects of Aukštaitian; it loses its tonal melody in the innovating Aukštaitian dialects ${ }^{3}$. The circumflex is rising-falling in Žemaitian and (more or less) rising in Aukštaitian. Thus, Halle and Kiparsky's

${ }^{3}$ Cf. Zinkkevičius (1966: 33ff), Buch (1967: 207, 1970: 1f), Mikalauskaiṫ (1975: 77ff), 140f, Hasiuk (1978: 17). 
identification of the contrast between acute and circumflex as a contrast between high tone and rising melody is based on a gross simplification of the data. It should be clear that this anti-empiricist attitude toward the facts is an intrinsic property of their theoreticaI framework.

3. Halle and Kiparsky stick to the traditional view that the contrast betwcen acute and cirumflex continues a contrast between Indo-European long and short vowels and that the tonal contrast became distinctive as a result of the shortening of long diphthongs (165). This is definitely a step backward if compared with Garde's view that the acute reflects an Indo-European syllabic nucleus which ended in a laryngeal, whereas the circumflex represents any other type of syllable (302ff). Though the latter formulation cannot be maintained (cf. Kortlandt 1978b: 280), it is doubtless closer to the truth.

Halle and Kiparsky object to Garde's "ad-hoc category non-acute, referring to syllables that are either short, or long with circumflex melody - an arbitrary conjunction of entities within G's framework. Within our framework, non-acute syllables are those which have the LH melody prior to Melody Simplification" (171). Why do non-acuto syllables have the LH melody in their framework? Because the authors assign LH to Indo-European short vowels and $\boldsymbol{H}$ to Indo-European long vowels and specify the synchronically contrary cases in the underlying lexical representation (165). In Garde's framework, tho (phonetically unspecified) acute continues the Indo-European final laryngeal of a syllabic nucleus. This conception was first put forward by Vaillant (1936: 114f, 1950: 244f) and has recently been shown to account, in a somewhat altered form, for a large array of hoterogeneous facts (Kortlandt 1975a and 1977). It has roceived a splendid confirmation by the discovery of Winter's Law'. As I have argued in detail elsewhere, the Balto-Slavic acute must have been a glottal stop which was preserved up to the 8 th century A. D. in Slavic (1975a: 34) and which has been preserved until the present day in Latvian (1977: 324). This not only eliminates Halle and Kiparsky's objection, but shows how their theoretical framework has prevented them from arriving at the correct solution. Their naive

4 Cf. Winter 1978 and my comment ibidem (447). 
identification of the Balto-Slavic acute and circumflex with the corresponding categories in a simplified account of modern standard Lithuanian and their predilection for theoretical reasoning rather than empirical study do not enable us "to gain a deoper understanding of the accentual phenomena of Baltic and Slavic" (161); on the contrary, they block the road toward further advances in understanding the empirical subject matter.

4. According to Halle and Kiparsky, "the formulation of Saussure's Law is rendered more perspicuous" as a result of their assignment of LH to short vowels and diphthongs. They formulate it as a tone flop rule "which detaches a $\mathbf{H}$ tone from the phoneme with which it was originally associated, and links it to the next tone-bearing phoneme" (171). The presentation of this formulation as a new proposal does not do justice to F. de Saussure, who put forward the same proposal 85 years earlier in a footnote (1896: 157), though he did not, of course, call it a 'tone flop rule'.

For Latvian, Halle and Kiparsky assign high pitch to historically long syllables that were originally accented, rising melody and glottal stop to historically long syllables that were originally unaccented, and falling melody to historically short syllables (174). This assignment is again based on a simplified account of the standard language. The authors give no explanation for the rise of a glottal stop in unaccented acute syllablos, the reversal of LH to HL melody in eircumflex syllables, or the merger of the falling tone with the rising tone with glottal constriction in the dialects of western Latvia.

5. In Early Slavic, shortly after its separation from Baltic, the acute was lost in pretonic syllables and eliminated culogically in barytone forms of mobile paradigms (cf. Suang 1957: 10). Elsewhere I have given a reasoned explanation for this developmont, which is known as Meillet's Law (1975a: 10f). It is possible that the analogy did not affect the word for 'mother', which shows the reflex of the acute in Czech, Slovene, and Serbo-Cront, and has mobile accentuation in a number of Slavic dialects (e.g., Novi Čakavian $)^{5}$.

5 More probably, this word preserved the Indo-European fixed stress on the first syllable in Balto-Slavic and Italo-Celtic and adopted the accentual mobility of the words for 'father' and 'daughter' in Sanskrit, Greek, 
According to Garde, Meillet's Law does not involve an analogical development because barytone forms of mobile paradigms were unaccented at that stage (198). Elsewhere I have shown why this point of view rannot be maintained (1978a: 75). The rise of unacented forms in Slavic was posterior to the generalization of accentual mobility in the Slavic non-acute masculine o-stems, a development which was established by Illič-Svityč (1963: 119 $=1979:$ 103). This analogical development was a consequence of the fact that the two accentual paradigms had merged in the singular. If the barytune case forms of the mobile paradigm had been unaccented at this stage, the analogical development could not have taken place. Since acute roots did not take part in the change, we have to conclude that there were no acute mobile paradigms any more at this stage, which was therefore posterior to Moillet's Law. Another reason for rejecting Garde's dating of the rise of unaccented forms is found in the leveling of pitch in prefixes. Slavic lost its acute prefixes except those which were not also used as prepositions ( $p a-, p r a-, v y$-), e.g. SCr. národ 'people'. The new tone on the prefix was apparently based on the tone of the preposition at a stage when the latter had lost the acute as a result of Meillet's Liw. Thus, the development of the new tone on prefixes requires a stage which was posterior to Meillet's Law, but anterior to the rise of the unaccented forms.

Halle and Kiparsky take another step away from the established facts and claim that the neutralization of the opposition between acute and circumflex in all weak morphemes marks the break-up of the Balto-Slavic unity (160); "unaccented syllables in Slavic lost their inherent tonal contrasts, and were uniformly assigned $\mathrm{L}$ tone in the lexicon" (174). Here again, their amendment is determined by a priori reasoning and lack of concern about the data. In addition to the objections which have just been mentioned and which the authors do not discuss, it raises a number of insuperable problems in connection with the attested quantity in posttonic syllables. West Slavic shows two different quantities

and Germanic (cf. Kortlandt 1981b: 13f, where I was reluctant to accept this possibility, in spite of the difference between the Avestan acc. pl.

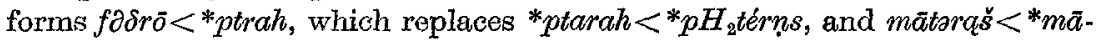
trns $<^{*}{ }^{*}$ é $_{2}$ trns $)$. The word has fixed stress in the majority of archaic dialects of Baltic and Slavic. 
in originally unaccented syllables, e.g. Czech holub 'pigeon', zalud 'acorn', labut' 'swan', oblast 'region' versus mësic 'month', peníz 'coin', jestrúb 'hawk', pavouk 'spider', ef. also pekaŕ 'baker' as opposed to rybar 'fisherman', where the attested reflexes aro the exact opposite of Halle and Kiparsky's predictions. This difference receives a natural explanation if we assume that the acuto was lost earlier in pretonic syllables than in posttonic syllables (cf. Kortlandt 1975a: 30). The ant quity of the quartitative difference is corroborated by the South Slavic cvidence (Kortlandt 1976: $5 \mathrm{f}$ ). In addition to the above eximples, all of which hare a non-acute rowel in the second syllable, there is a quantitative difference between acute and non-acute vowels in the first posttonic syllable in South Slavic, o.g., SC: krästav 'scabby' versus lerävāor 'cowherd', Sln. krástav versus krâvar (with neo-circumflex reflecting exrlier posttonic length), ef. Dybo 1968: :167ff, 193ff. Moreover, the hypothesis that the acute was preserved longer in the first posttonic syllable than in following syllables provides us with a natural explanation for the rise of noo-circumflex in trisyllabic words which shifted the stress from the first to the second syllable as a result of the progressive accent shift (ef. Kortlandt 1975a: 11, 1976: 3f). All these problems remain beyond the limits of Halle and Kiparsky's framework. Thoy show how an approach which is based on theoretical reasoning and loose universalist notions can lead one astray if it is not supported by a sufficient knowledge of the facts.

In my view, the acute was lost in pretonic and post-posttonic syllables in Early Slavic, while it was retained in the stressed syllable and in the first posttonic syllable until the general loss of final consonants and concomitant changes led to the characteristic absence of closed syllables in Slavic. The loss of the acute in the first posttonie syllable entailed the rise of the new timbre oppositions: short * $a$ became rounded $o$, acute $* a$ ? became short $a$, non-acute long * $\bar{a}$ was shortened to $a$ in protonic syllables but remained long $\bar{a}$ under the stress and in posttonic syllables, ete. (Kortlandt 1975a: 29, 1978b: 277)

6. The basis of modern Slavic accentology was laid in Stang's classic monograph (1957), the importance of which can hardly be overestimated. The author established the existence of three accent paradigms in Late Proto-Slavic: 
(a) a paradigm with fixed stress and acute intonation on the stressed syllable,

(b) a paradigm with accentual mobility between adjacent sylkbles and neo-acute intonation on a non-final stressed syllable,

(c) a paradigm with accentual mobility between the initial and the final syllable of the word and circumflex intonation in a stressed initial syllable. The latter paradigm had the same siress pattorn as the Lithuanian mobile paradigm before the operation of Saussure's Law.

Stang concluded that the neo-acute intonation had ariscn as a result of a retraction of the stress from the following syllable und that paradigm (b) had had fixed stress on a non-initial syllible at an earlior stage. Since at that stage type (b) had fixed stress on a. non-initial syliable and type (a) had fixed stress on a non-final acute syllable, these two accent paradigms were in complementary distribution. The rise of type (b) can therefore bo explained if we assume that a non-acute stressed vowel had lost the stress to the following syllable at an earlier stage in the development of Slavic. This is the progressive accent shift which was establisher by Dybo (1962) and Illič-Svityč (1963), and which is called Dybo's Law by some authors (c.g., Ebeling 1967, Kortlandt 1975a) and Illič-Svityč's Law by others (e.g., Garde 1976). Since there is wide disagreement about the exact conditions of the progressive accent shifi, I will shortly review the different positions which various authors have taken with respect to the Proto-Slavic tonal system at tho time of the shift.

Dybo imagines the developments as follows (1962: 8f): "Tho whole chain of processes can be represented in the following way: 1) the rise of a special intonation in the mobile acute paratigm (a situation which is analogical to the one reflected in the Latvian dialects with three intonations); 2) the spread of this intonation to words of the mobile paradigm with an originally circumflex or short root (neutralization of accentual oppositions in the mobile paradigm); 3) further changes take place within the limits of clementary phonological oppositions: a change of the phonetic character of the new intonation and its approach to the character of the circumflex brings about that the intonation starts exerting pressure upon the circumflex, and this leads to a change of the circumflex intonation, the shift of the stress to the following syllable, and the rise of the neo-acute". Though this is indeed a 
possible chain of events, Dybo's theory does not provide a reasoned explanation for the separate derolopments. It has the merit of making clear that the progressive accent shift requin es the existence of a threefold tonal opposition on stressed initial syllables at a stage which is anterior to the late Proto-Slavic retractions of the stress, and this is why I stick to calling the shift 'Dybo's Law'.

Illic-Svityc assumed that all non-acute stressed syllables were falling and held the following view $(1963: 161)^{6}$ :

As is known, at a later stage of Pre-Slavic internal syllables with falling tone were phonetically impermissible. The accent was shifted from such syllables to the preceding syllable, resulting in a neoacute tone. It may be assumed that the tendency toward the elimination of falling tone in internal position began rather early in Pre-Slavic; originally, internal accent could have been elimmated by means of a shift to the following syllable. This assumption would explain the transformation of the proposed forms of the barytone AP into oxytone forms * (vü $l \phi k Q$ to * $v \breve{u} l Q k \phi)$; the complete transformation of the paradigm into oxytone could be ascribed to the operation of analogy: *lokke to *lgkg under the influence of *vü $l_{Q k} \phi$, and *lika to *loka under the influence of *lokè and vŭ lọkò.

If this theory were correct, we winld expect traces of the original distribution of phonetically and analogically end-stressed forms, which we do not find. Indeed, the theory predicts the opposite of the attested distribution in Russ. tuda 'thither', ottida 'thence', Ukr. mené 'me', do méne 'to me'. Dybo's account, which draws the logical conclusion from the phnnetic character of the accent. shift, is doubtless to be preferred.

Ebeling, like his predecessors, sticks to the traditional view that Indo-European long vowels and diphthongs became rising while Indo-European short diphthongs became falling at an early stage (1967: 583). He assumes that stressed initial short and falling syllables in mobile paradigms received a different intonation (circumflex) from short and falling syllables in all other positions (unspecified) and adds: "I am unable to determine any nearer the phonetic nature of this difference" (586). The unspecified intonation disappeared from the system when syllables of this type lost the stress to the following syllable in accordance with Dybo's Law (590). In this theory, both the rise of the new tonal contrast and the progressive accent shift remain unexplained.

8 The translation is taken from Illič-Svityc 1970: 144. 
The core of my own theory is the identification of the Proto-Slavic acute with a glottal stop. The correctness of this identification has unexpectedly been confirmed by the discovery of Winter's Low (cf. Kortlandt 1978c). In my riew, stressed initial syllables in mobile paradigms received a falling tone (HL), while all other stressed syllables became rising (LH). This tonal contrast has a twofold origin. The rise of the falling tone must be conrectod with the Slavic retraction of the stress to prepositions and prefixes (Kortlandt 1975a: 28), which cannot be iclentified with the corresponding phenomenon in Lithuanian (cf. Kortlandt 1977: 326). The falling tone, which has been preserved essentially unchanged in the archaic dialects of Serbo-Croat, can be regarded as a sequence of a floating $\mathrm{H}$, which is suppressed if there is another $\mathrm{H}$ in the same accentual unit, and a lirked $\mathrm{L}$, which remains attached to the initial syllable. The origin of the rising tone is the well-known Law of rising sonority (or Liw of open syllables, cf. Van Wijk 1931: 46ff). These developments belong to what I hare called the Middle Slavic period (1979: 263). At a later stage, which I have called Young Proto-Slavic, the redurdancies which the trend toward rising sonority had created evoked a reaction which led to the disintegration of the prosodic system and erentually to the rise of new closed syllables. In this conception, Dybo's Law is a tone flop rule which was blocked by the presence of a glottal stop. There appears to be a significant analogue of this development in Avar, to which Dybo et al. have recently drawn attention (1978: 18): "Avar possesses a system of three accent paradigms - two with immobile stress on the root (stress on the first syllable - paradigm A, stress on the second - paradigm B) and one with mobile stress (paradigm C)." The distribution of the Avar paradigms A and B is similar to that of the Slavic paradigms (a) and (b): "we may suppose that originally words of both paradigms were stressed on the first syllable, but later stress shifted to the second syllable from the first non-pharyngealized one (in Avar, thus, pharyngealization plays the same role as length in Slavic)" (19). If we replace the word "length" in the last sentence with "glottalization" or "laryngealization" or "pharyngealization" in accordance with my theory on the phonetic nature of the Balto-Slavic acute, we obtain a perfect parallel. A comparison of the Avar accent paradigms with the tonal system of the related Tindi 
langrage shows that paradigm $B$ corresponds to Tindi level and rising tones while paradigm $\mathrm{C}$ corresponds to the Tindi falling tone (Starostin 1978: 88f). Thus, the typological evidence from Avar, like the comparative ovidence of Winter's Law, offers a posteriori support for my theory on the history of Slavic accentuation ${ }^{7}$. Further progress in this field of study requires a large-scale descriptive effort which is not lampered by theoretical prejudices.

7. As we have seen above, Garde leaves the phontic nature of 'acute' and 'circumflex' unspecified (section 2) and regards barytone forms of mobile paradigms as maccented (section 5). If a word from the latter category is neither preceded by an accented word nor followed by a clitic, it receives a 'recessive accent' on its initial syllable. This terminology is rather awkward because it is the exact opposite of the one used in Stang's classic monograph (1957): the latter author uses 'circunhlex' in the traditional sense, which corresponds to Garde's 'recessive aceent', while he uses 'recessive stress" for the neo-acute, which eorresponds to Garde's 'circumflex' ${ }^{8}$. The real problem which poses itself in this connection is the tonal eharacter of Garde's 'recessive accent'. Was the surface representation of this accent di.tinct from the surface representation of a fixed accent on a non-acute syllable or not? Garde's notation of his 'recessive accent' as a bracketed tick mark suggests that it was not, which is in atecordance with Illič-Svityě's view cited above ${ }^{9}$. Unlike Illič-Svityě, Garde does not bave to assume wholesale analogical change becauso the 'recessire accent' is in his view a variant of unstressed syllabicity. He does not provide an explanation for the shift of a non-acute accent to the following syllable.

- Similarly, Avar provides an analogue of Hirt's Law m Balto-Slavic, as Dybo of al. have indicated (ibidem).

${ }^{8}$ Halle and Kiparsky have apparently fallen victims to this terminological confusion in their footnote 13 (175). The use of strong language in this footnote does not help to elucrdate the differences of opinon and seems rather out of place in an account whinh contributos so littio to a better understancling of the subject matter.

9 When I met Professor Garde near Cracow in October 1980 and put the question before him, he told me what he did in fact assume a surface distinction, which is in accordance wh Dybo's view cited above. This eliminates one of the major disagreeneats between the two of us. 
Halle and Kiparsky substitnte High, Low-High, and Low for Garde's 'aciste', 'circumflex', and 'unaccented', respectively. As we have seen above, the identification of the acute with a high tone is mislealing, the assignmont of rising melody to non-acute accented syllobles was proposol six years earlier by the present author (1975a: 14, 28), and the identification of the traditional circumflex with unaccentedness which they took from Garde generates a number of problons which they do not discuss. They view the phenomena which are explained by the assumption of a progressive accent shift "as by-products of the specifically Slavic restriction on the number of trnes that could be linked with a single phoneme in the lexicon" (176). They regard the rising molody as a linked $\mathrm{L}$ and a floating $\mathrm{H}$, the latter of which is assigned to the next syllable by their Tone Association Rule, which associates tones with tone-bearing bhonemes from left to right (163). Thus, "when Slavic limited to one the number of tones that could bo linked with in single tone-bearing phoneme in lexical representation, stems with LH molurly (and only these) automatically became post-accenting" (176)

Halle and Kiparsky's viow cunnot be maintained for chronoJogical reasons. Elsewhere I lave shown that the retraction of the stress from final jers, which gave rise to new rising tones in prefinal syllables, was anterinr to the progressive accent shift (1975a: 15). Tho lack of chronological perspective in their theoretical framework has prevented Halle and Kiparsky from porceiving the problen, let alone the solution. Here again, their view is based on a priori reasoning and lack of encern about the data.

8. According th Gdrde, the jow mive aceent shift dirl not operate in the West slavic languary (208ff). In my revicw of Garde's book, I have pointed out why this position cannot be maintained (1978a: 76fi), Halle and Kipusshy claim that in Wost Slavic the accent shift affected short syllibles only and that this is a consequence of the licet that West Slavie, unlike South and East Slavic, did not elinindo mora struetur. (277f). Since they have not found it necessary to discuss the conn w vidonce which I adducod against this point of viow in my revin w w barde's work, it snems inevitable to repeat the rolevant data lis

Firstly, these is in Slovirnan (Kashubian) an aceentual differ- 


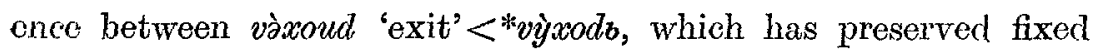
stress on the initial syllable because the vowel was acute, and composita like droxoud 'income' $<{ }^{*} d o x o ̀ d b$, where accentual mobility reflects non-initial stress as a result of the progressive accent shift. If the accent shift had not affected long vowels, we would expect fixed stress in nouns like príxoud 'arrival'. In fact, the latter word has mobile stress, which points to *prixxòdz, with non-initial stress as a result of the accent shift. The preservation of fixed stress in vàxoud, and also in the composita with a nonsyllabic prefix, shows that the accentual mobility of prixoud cannot be analogical.

Secondly, feminine nouns like zäbàva 'entertainment' and voutrìoba 'liver' have a pretonic long vowel which can only have arisen as a result of the accent shift. These words show that the Slovincian retractions of the stress were limited to final syllables. It must be regretted that Halle and Kiparsky have chosen to disregard the contrary data, which were known to them at the time of writing the article. This way of handling the evidence demonstrates the dangerous consequences of a theoretical framework which is based on general considerations instead of empirical study.

9. While Garde is at pains to account for the facts in terms of a suitable theoretical framework and to present the data as clearly and explicitly as possible when he is unable to provide an adequate explanation (e.g., $218 \mathrm{ff}$ on the Slavic retractions of the stress), disregard of the facts is the red thread which runs through Halle and Kiparsky's alternative treatment. Consider e.g. their discussion of the quantitative refiexes of tone (179). "Long stems of Paradigms $\mathrm{B}$ and $\mathrm{C}$ are treated differently in West Slavic, but they are treated identically in the other Slavic languages". Actually, a long stem vowel is shortened in polysyllabic forms of paradigm (c), but not (b), in South Slavic, e.g. SCr. mlädõst 'youth', präseta 'pig' (gen. sg.), rùkkama 'hand' (obl. pl.), cf. mlâd 'young', nom. sg. prâse, ruika. The long vowel of weak stems was also shortened in jèzik 'tongue', màlina 'raspberry', bjèžati 'to flee', whereas the long vowel of non-acute strong stems was nover shortened. "We noted above that South and West Slavic were subject to Rule 10, which shurtens vowels with acute melody". They do not discuss the long 
reflex of the acute in Czech, e.g. kráva 'cow', bráti 'to take'. "East. Slavic was not subject to shortening because it lost quantity contrasts rather early, before shortening became effective". They do not discuss the difference between Ukr. moro'z 'frost', with short $o$ reflecting the acute, and gen. pl. holk $v$ 'head', with $i$ from long ${ }^{*} \bar{o}$ reflecting the neo-acute (Halle and Kiparsky's 'circumflex'). The shortening of long vowels in polysyllabic forms of weak stems is ignored in their statement that "in South Slavic, shortening was limited to vowels with $\mathrm{H}$ tone". They assign $\mathrm{L}$ to the formative vowel in the $n$-participle, where the comparative evidence points to IH (cf. Kortlandt 1975a: 7f). They invoke an unspecified "special morphophonemic rule" for the retraction of the stress in the n-participle without mentioning Stang's Law, which was the foundation of the work by Dybo and Illic-Svityě. They illustrate the statement that "in West Slavic, only words with rising melody (LH) preserve the original length" with the Slovak past tonse form viieklo 'pulled' (n. sg.). This is a particularly unfortunate example becarise the stem vowel is also long in the past tense of hryzt', Klást', liezt', pást', priast', siect', which have a Proto-Slavic acute (cf. SCr. grïsti, klästi, ljësti, pästi, prêsti, sjëći), and in the past tense of hriest', hriebst', miest', niest', piect', pliest', riect', tiect', viest', viezt', which have a Proto-Slavic short vowel (ef. Nonnenmacher-Pribić 1961: 108). Most probably, length spread from the masc. sg. form of the past tense of the mobile paradigm, where it had originated from the rotraction of the stress from the final jer, e.g., piekol 'baked'<"pélllo<*peklz. It did not reach the vocalic stems, which have retained the original distribution, and the verb môct' 'can', which never had an end-stressed mase. sg. form in the past tense: mohol <*mòglz, mohla, mohlo, mohli.

To summarize: Halle and Kiparsky's alternative theoretical framework does not help to gain a better understanding of the subject matter, in spite of the authors' claims. It rests upon an unwarranted limitation of the available evidence, obscures the chronological perspective, and yields results which are partly not new and partly incorrect. It is harmful because it does not give the facts their proper due and thereby blocks the road to empirical study, giving a free hand to unrestrained speculation. Linguistic theory and typological considerations play an important role in the evaluation of the data but must never be allowed to 
incite the investigator to suppress comter-evidence. The establishment of universals requires a large-scalo descriptive effort because linguistics is, after all, an empirical discipline. ${ }^{\mathbf{1 0}}$

\section{FREDERIK KORTLANDT Cobetstraat 24 \\ $2313 K C$ LEIDEN HOLLAND}

\section{REFERENCES}

Buch, T.

1967 "Mundartlicher Intonationsschwund im Litauischen", Die Welt der Slaven 12: 205-8.

1970 "Entwicklungstendenzen in der Alzzentuierung der Substantive im Litauischen", International Journal of Slavic Linguistics and Poetics 13: 1-10.

Dybo, V. A.

1962 "O rekonstrukcii udarenija v praslavjanskom glagole", Voprosy slavjankogo jazykoznanija 6: 3-27.

1968 "Akcentologija i slovoobrazovanie $\mathrm{v}$ slavjanskom", Slavjanskoe jazykoznanie 6: 148-224.

1973 "Baltoslavjanskaja akcentnaja sistema s tipologičeskoj toŭki zrenija i problema rekonstrukcii indoevropejskogo akcenta", Kuznecovskie čtenija 1973: Istorija slavjanskix jazylov i pis'mennosti, (Moskva: Nauka), 8-10.

Dybo, V. A., Nikolayev, S. and Starostin, S.

1978 "A tonological hypothesis on the origin of paradigmatic accent systems", Estonian Papers in Phonetics (Tallinn: Academy of Sciences), 16-20.

10 An example of how theoretical reasoning can block further advanees in understanding the facts is provided by Joseph Greenberg's "general diachronic hypothesis that at least one source of injectives might be a sound shift from voiced plain to voiced implosive stops, since such a change would result in a system of an attested type, namely ono in which there were injective but not plain voiced stops. There is at least one historically documented example of this development, namely Sindhi" (1970: 134). A closer inspection of the Sindhi data suggests that the implosives wero inhorited from Proto-Indo-European (cf. Kortlandt 198Ia). This suggestion is $110 \mathrm{~W}$ corroborated by evidence from Vedic and Avestan (Lubotsky 1981). The converse of Greenberg's hypothesis could have put somebody on the right track in evaluating the Sindhi material. The aim of this romark is to caution against rash generalizations on the basis of theoretical reflections, not to falsify Greenberg's hypothesis (which may or may not be correct). 
Iiboling, C. L.

1967 "Historical laws of Slavic accentuation", To honor Roman Jakobson (The Hague: Mouton), 577-93.

Garde, $P$.

1976 Histoire de l'accentuation slave (Paris: Institut d'études slaves). Greenberg, J. $\mathrm{H}$.

1970 "Some generalizations concerning' glottalic consonants, especially implosivos", International Joumal of American Linguistics 36: $123-45$.

Hallo, M. and Kiparsky, P.

1981 Review of Garde 1976, Language 57: 150-81.

Hasiuk, $M$.

1978 Fonologia litewskiej guary sejneńskiej (Poznań: Uniwersytet im. A. Mickiewicza).

Illi.̌.Svityč, V. M.

1963 Imennaja akcentuacija $v$ baltijskom $i$ slavjanskom: Sud'ba akcen * tuacionnyx paradigm (Moskva: Akademija Nauk).

1979 Nominal accentuation in Baltic and Slavic (Cambridge, Mas.: The MIT Press).

Kortlandt, F.

1975a Slavic accentuation: A study in relative ohronology (Lisse: Peter de Ridder).

1975b "Tones in Wakashan", Linguistics 146: 31-4.

1976 "The Slovene neo-circumflex", The Slavonic and East European, Review 54: 1-10.

1977 "Historical laws of Baltic accontuation", Baltistica 13: 319-30.

1978a "A history of Slavic accentuation", [Review of Garde 1976] Lingua 44: $67-91$.

$1978 b$ "On the history of Slavic accentuation", Zeitschrift für vergleichende Sprachforschung 92: 269-81.

1978 c "Proto-Indo-European obstruents", Indogermanische Forschungen 83: 107-18.

1979 "On the history of the Slavic nasal vowels", Indogermanische Forschungen 84: 259-72.

1081a "Glottalic consonants in Sindhi and Proto-Indo-European". Indo-Iranian Journal 23: 15 -9.

$1981 \mathrm{~b}$ "More evidence for Italo-Celtic", Ériu 32: 1-22.

Lubotsky, A.

1981 "Gr. pégnumi: Skt. pajrám and loss of laryngeals before mediae in Indo-Iranian", Münchener Studien zur Sprachwissenschaft 40: 133-8.

Mikajauskaite, E.

1975 Lietuviu kalbos fonetikos darbai (Vilnius: Mokslas).

Nonnenmacher-Pribić, E.

1961 Die baltoslavischen Alszent- und Intonationsverhältnisse und ihr quantitativer Reflex im Slovakischen (Wiesbaden: Harrassowitz).

Rach, J. C.

1981 A practical Heiltsuk-English dictionary (Ottawa: National Museum of Man). 
Saussuro, F. de

1896 "Accentuation lituanienne", Anzeiger für indogermanische Sprachund Altertumsteunde 6: 157-66.

Stang, C. \$.

1957 Slavonic accentuation (Oslo: Universitetsforlaget).

Starostin, S.

1978 "Preliminary remarks on accent correspondences between some languages of Dagestan", Estonian Papers in Phonetics (Tallinn: Academy of Sciences), 88-90.

Vaillant, A.

1936 "Le problèmo des intonations balto-slaves", Bulletin de la Société de Linguistique de Paris 37: 109-15.

1950 Grammaire comparée des langues slavesI: Phonétique (Lyon: IAC). Van Wijk, N.

1931 Geschichte der altkirchenslavischen Sprache I: Laut- und Formenlehre (Berlin: De Gruyter).

Winter, W.

1978 "The distribution of short and long vowels in stems of the type Lith. ésti : vèsti : mèsti and OCS. jasti: vesti : mesti in Baltic and Slavic languages", Recent developments in historical phonology, edited by J. Fisiak (The Hague: Mouton), 431-46.

Zinkevičius, $\mathrm{Z}$.

1966 Lietuviu dialektologija: Lyginamoji tarmiu fonetika ir morfologija (Vilnius: Mintis). 